\title{
Parametric Study of the Thermal Performance of a Single-family House Equipped with an Airflow Window integrating a Heated Glazing
}

\author{
M. Kaboré ${ }^{1,3}$, G. Michaux ${ }^{1}$, J. Le Dréau ${ }^{1}$, P. Salagnac ${ }^{1}$, R. Greffet ${ }^{2}$ \\ ${ }^{1}$ LaSIE (UMR CNRS 7356), La Rochelle University, La Rochelle, France \\ ${ }^{2}$ Groupe Ridoret, ZI Chef de Baie, La Rochelle, France \\ ${ }^{3}$ IRSAT/CNRST, Ouagadougou, Burkina Faso
}

\begin{abstract}
Airflow windows equipped with heated glazing offer the possibility to partly recover at the same time thermal losses through the window as well as the heated glass ones. Indeed, heat is recovered by the fresh air coming from the outside and flowing between the window panes before its introduction into the building. Using a twodimensional nodal model of the airflow window coupled to a single-family house thermal one, parametric studies have been carried out in order to evaluate the performance of the heated airflow window in terms of heating energy consumption. A slight increase of heating energy is observed depending on the windows exposure and the climate compare to non-heated airflow windows cases with electric convectors as a heating system. Comparisons to conventional double-glazed windows were also performed. Results show that it is more efficient in comparison to a double-glazed window case. It can be an alternative to conventional electric heating solutions and is suitable for buildings with a high air tightness.
\end{abstract}

\section{Introduction}

In the building sector, glazing and fresh air ventilation are today two major weaknesses in terms of building energy performances, and this is particularly true for passive buildings (losses of around $60 \%$ through glass walls and
$20 \%$ due to fresh air ventilation) (Feist \& Schnieders, 2009). Reducing building consumption requires to improve the building envelope components and systems performances. The envelope component considered here is an airflow window equipped with a heated glass (Figure 1) that can simultaneously meet several needs, namely ventilation, natural lighting and heating. The advantage is to partly recover heat losses by the circulation of outdoor fresh air through the glazing before its introduction into the building. Indeed, the entering fresh air is heated by partly recovering thermal losses through the window, energy from solar radiation absorbed by the glazing and losses of the heated glass (Figure 1B). The technology of heated glazing is based on the conductive properties of a transparent metal oxide (TCO) layer composed of metal microparticles deposited on the surface of the glass (Granqvist \& Hultåker, 2002; Gerhardinger, 2003). When the coating is connected to a power supply, it is crossed by an electric current. The metal coating then operates as a low temperature electric heater based on Joule effect. In comparison to conventional electric radiators and convectors, the main disadvantage of the heated glazing is to be in contact to the outdoor environment. Part of the heat emitted by the system is thus directly transmitted to outdoor environment. Heated windows can help to avoid draft and asymmetrical radiation always caused by

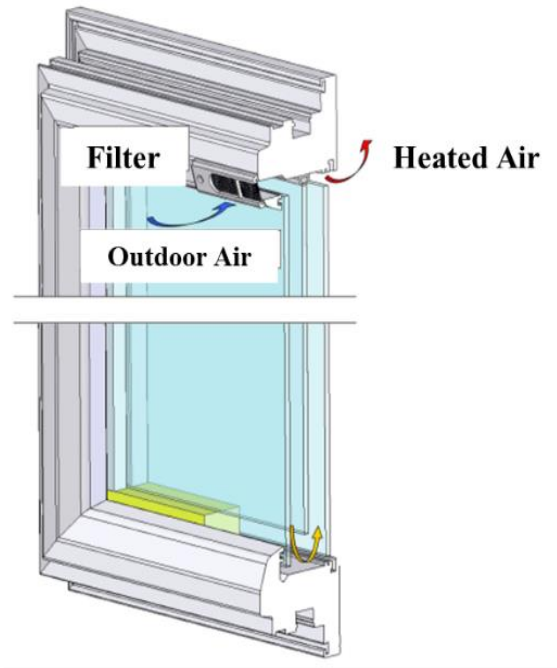

A

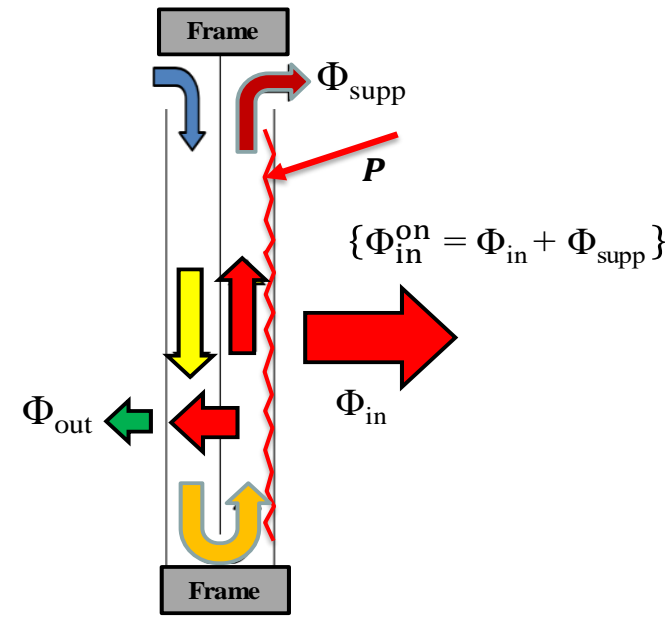

B

Figure 1 A: Schematic view; B: working principle of the studied airflow window. 
conventional heating systems, particularly if associated with poor U-value windows.

Kurnitski et al. (2004) have defined and numerically studied the efficiency of the heating glazing. This efficiency, noted $\mathrm{E}_{\mathrm{w}}$, only accounts for the additional losses due to the heated window (compared to a nonheated window). The authors have shown that, for a given indoor temperature, the effectiveness of such a device depends on the outdoor temperature and the thermal resistance of the glazing. The efficiency of a conventional heated glazing unit $\left(U=1.1 \mathrm{~W} \cdot \mathrm{m}^{-2} \cdot \mathrm{K}^{-1}\right)$ is 0.78 at $-10{ }^{\circ} \mathrm{C}$ and reaches, for the same temperature, 0.89 for extremely efficient glazing $\left(U=0.6 \mathrm{~W} \cdot \mathrm{m}^{-2} \cdot \mathrm{K}^{-1}\right)$, i.e. for triple glazing with two low-emissivity layers. Kurnitski et al. (2004) have finally demonstrated that the efficiency is proportional to the U-value of the window. In terms of thermal comfort, one of the advantages of heated window is to create a more homogenous environment by canceling the phenomena of cold wall. The heated window creates a more uniform radiant environment, but stratification can occur if the supplied air is too warm. These problems of stratification are usually accounted for by applying an emission efficiency to the emitter, which mainly depends on the convective share of the heating system. As an example, the emission efficiency of an air heating system is estimated at 81-93\%, and that of a radiator at 83-95\% (DIN V 18599-2, 2007).

Many patents have been filed on the heating glazing (principle, composition of the coating, electric connectors, etc.), but only a few relates to the association of a heated glass to an airflow window, and the literature on this subject is limited to the following patents. A patent was published in 1990 by Saint-Gobain Vitrage International (Fremaux \& Brechot, 1990), and is aimed to add heated glazing system to existing windows. Another Saint-Gobain patent concerns a heated laminated glass offering a better rate of light transmission (Chaussade \& Rigal, 1997). In fact, the layers of metal oxides used to make low-emissivity or heated glasses have a negative impact on the optical properties of the glasses (solar factor and light transmission).

About scientific literature, to our knowledge, there is no result on the thermal performance of an airflow window equipped with a heated glazing. In the present study, using a two-dimensional nodal model of an airflow window integrating a heated glazing (HAF) coupled to the thermal model of a typical single-family home, parametric studies on the final energy consumption for heating are conducted. Considered parameters are the building location (climate), exposure (orientation), and envelope quality (air tightness). We also compare its performance to the more conventional windows technologies such as double-glazed window (DG), heated double-glazed window (HDG), and non-heated airflow window (AF).

\section{Methods}

\section{Numerical model}

The model has been adapted from the two-dimensional model developed by Greffet et al. for an airflow window without heated glazing (Greffet et al., 2013; Greffet et al., 2015; Greffet, 2016). Its principle is illustrated by Figure 2. A nodal approach was used to model the heat and mass transfers within and through the window. Air, coming from the outside, enters into the window through an opening located in the upper part of it on its outer face (Figure 1). Air first flows downward between the first two panes, and then upward between the second and third panes before entering the room through an opening located in the upper part of the window (inner side). Heat transfers are conductive into glass panes and the frame, and radiative, fluidic and convective within air layers and at the interfaces with the indoor and outdoor environments (Figure 2).

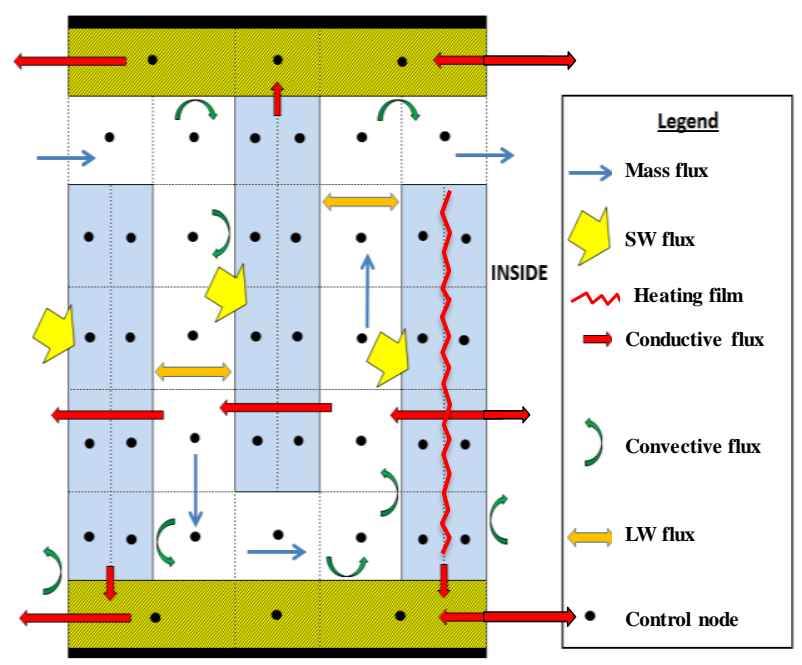

Figure 2: View of the modeled airflow window showing heat and mass transfers.

The radiative heat transfers considered are, on the one hand, the shortwave solar radiation inputs (SW), partly absorbed by the glass volumes (semitransparent medium) and, on the other hand, longwave radiative exchanges (LW) between glass surfaces and indoor and outdoor environments. The model also takes into account heat transfers with the frame. The heat transfers with the frame parts on both sides of the glazing are therefore modeled. To take into account the effect of the heating film, we impose a power density within the surfaces of the inner pane (Figure 2) meaning the third glass from outside (Kaboré et al., 2018). The window is divided into 56 control volumes. For each of these volumes, a heat balance has been written and leads to a system of ordinary differential equations (Greffet, 2016; Michaux et al., 2019). By writing the thermal balance for the airflow window, we obtain the following differential equations system:

$$
\begin{gathered}
C \dot{\vec{T}}=A \vec{T}+\vec{B} \\
\rho_{i} C p_{i} V_{i} \frac{\partial T_{i}}{\partial t}=\left(G_{i}^{f}+G_{i}^{C D}+G_{i}^{C V}+G_{i}^{R}\right)\left(T_{j}-T_{i}\right)+\Phi_{i}
\end{gathered}
$$

where $A$ is the conductance matrix, $\vec{B}$ the vector of heat flux, $C$ the thermal capacity matrix and $\vec{T}$ the temperature vector. $\rho$ is the density, $C p$ the specific heat, $V i$ the 
isothermal volume of the cell at the node $i$ and $\Phi_{i}$ the sum of external heat fluxes. The convective heat transfer coefficients were evaluated as a function of the airflow, for values ranging from 1 to $45 \mathrm{~m}^{3} \cdot \mathrm{h}^{-1}$, using Comsol Multiphysics® (Greffet et al., 2015).

\section{Building model}

The building studied here consists of a concrete envelope with thermal insulation from the inside and tile roofing, located on the INCAS experimental platform at INES (Bourget-Du-Lac) (Michaux et al., 2017). The house (Figure 3), whose floorplans are shown in Figure 5, was modeled with a multizone approach using TRNSYS $\odot$ Dynamic Thermal Simulation Code. All the doors between zones are closed. The building envelope is highly thermally insulated, the thermal resistances of walls, roof and floor are respectively $4.1,6.5$ and $1.7 \mathrm{~m}^{2} . \mathrm{K}^{-\mathrm{W}^{-1}}$. The building envelope is also characterized by a high airtightness $\left(Q_{4 \text { Pa_surf }}=0.4 \mathrm{~m}^{3} \cdot \mathrm{h}^{-1} \cdot \mathrm{m}^{-2}\right)$, which respect the French requirement $\left(Q_{4 \mathrm{~Pa} \_ \text {surf }}<0.6 \mathrm{~m}^{3} \cdot \mathrm{h}^{-1} \cdot \mathrm{m}^{-2}\right)$ for a new dwelling. Taking into account the compactness factor of the building an air tightness of $0.4 \mathrm{~m}^{3} \cdot \mathrm{h}^{-1} \cdot \mathrm{m}^{-2}$ corresponds to $n_{50}=2.4 \mathrm{vol} / \mathrm{h}$.

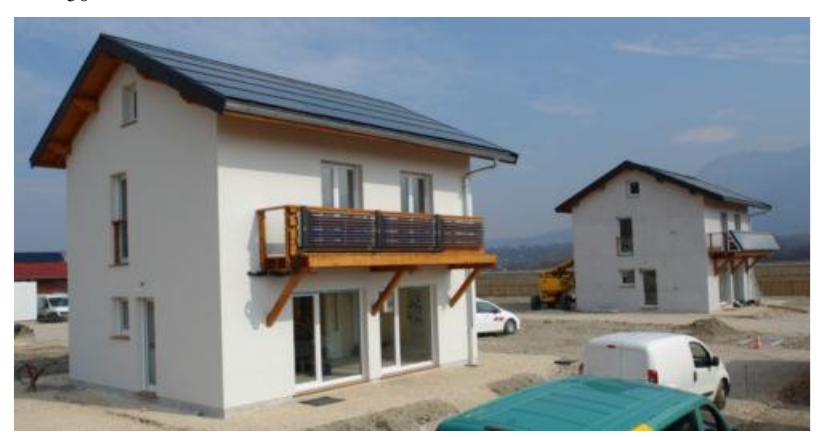

Figure 3: View of the studied building.

We considered that the house is occupied all the year and that the heating system is activated from October $1^{\text {st }}$ to May $20^{\text {th }}$. The heating setpoints are $20{ }^{\circ} \mathrm{C}$ during the occupancy period and $18{ }^{\circ} \mathrm{C}$ during the unoccupied period, with a night set-back of $16^{\circ} \mathrm{C}$ (Figure 4).

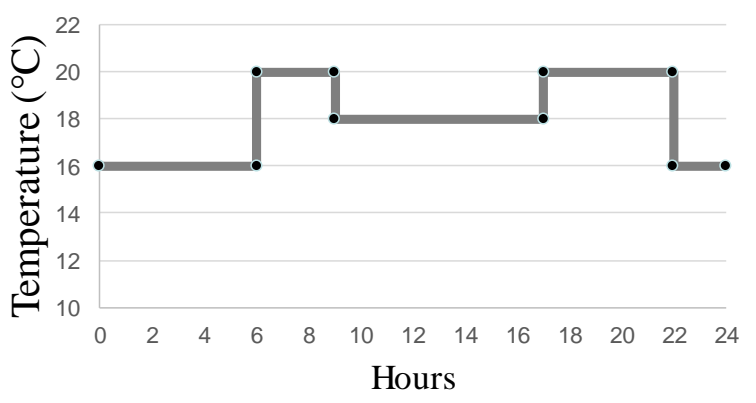

Figure 4: Heating schedule.

Main rooms (living room and bedrooms) are equipped with triple glazed airflows window with heated glass (4/15/4/15/4). These windows are the only heating system in these rooms (Figure 5) for heated windows cases. The average heating power most commonly found for heated glass ranges from 200 up to $300 \mathrm{~W} / \mathrm{m}^{2}$. In practice, for reasons of safety and durability of the joinery (thermal expansion), the power emitted by the glazing is limited by the temperature of its inner face, which must not exceed $45^{\circ} \mathrm{C}$. In the rest of the study, we will use a heating power of $300 \mathrm{~W} / \mathrm{m}^{2}$ for the living room and bedrooms. The heated glass is regulated tuned according to classical rules (Ziegler \& Nichols, 1993). Rooms without heated airflow window are equipped with conventional electric heaters (convective electric radiators).

Figure 5 shows air flows between zones. The indicated flow rates correspond to the case of a controlled mechanical ventilation of the self-adjusting type for which the fresh air flows are defined according to the French decree of 1982 (Arrêté du 24 mars 1982 relatif à l'aération des logements).

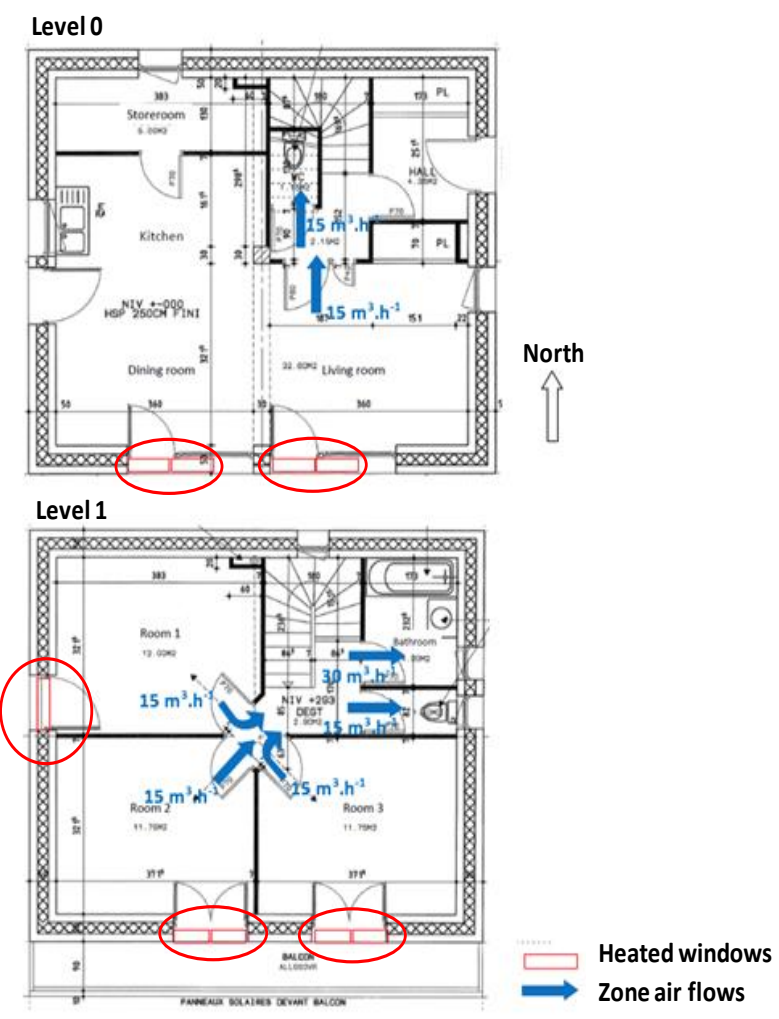

Figure 5: Building floorplans showing location of the heated airflow windows and air flows between zones.

In this case, the total extracted airflow is $90 \mathrm{~m}^{3} \cdot \mathrm{h}^{-1}$ all the time except from $1 \mathrm{PM}$ to $2 \mathrm{PM}$ where the airflow increases to $180 \mathrm{~m}^{3} \cdot \mathrm{h}^{-1}$. The flow of fresh air passing through the airflow windows is deduced from the ventilation rate and the infiltration of the envelope (Arrêté du 5 février 2015 relatif à l'agrément des modalités de prise en compte des fenêtres airflows dans la réglementation thermique 2012).

The two models (Michaux et al., 2017) communicate via a TRNSYS $\odot$ module linked to the Matlab $\odot$ module (Figure 6). In practice, airflow windows were integrated into the model of the building by assimilating them to walls with imposed temperature, integrated to the external walls and by calculating the inlet air temperature. Matlab calculates this imposed temperature at each time step by taking into account the preheating of the incoming air. 
Finally, the SW solar flux directly transmitted by the window is distributed to the different surfaces of the areas concerned (equal share between the floor and the walls facing each window).

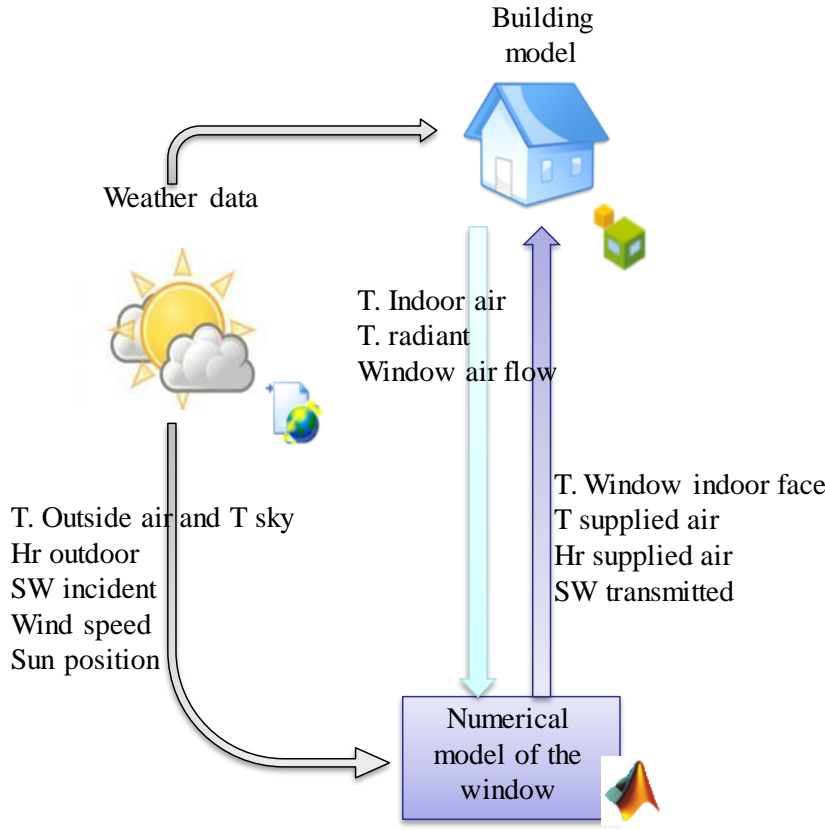

Figure 6: Coupling principle between TRNSYS and Matlab.

\section{Results and discussion}

\section{Temperatures and heat transfers analysis}

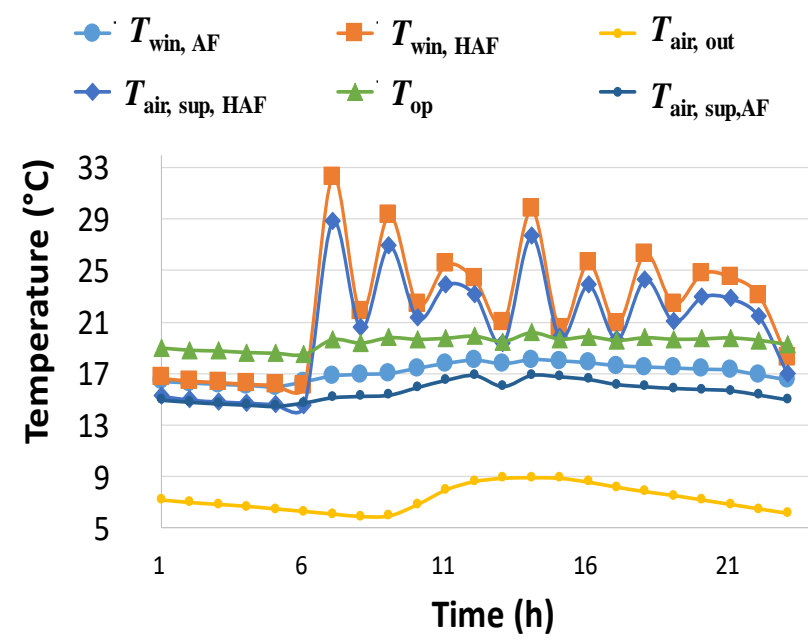

A
When the heated glazing is activated $\left(P_{\text {film }}>0\right.$ in Figure $7 \mathrm{~B}$ ), it is possible to observe the surface temperature levels for heating the building. The supplied air temperature $\left(T_{\text {air,supp,HAF }}\right)$ is close to the surface temperature ( $T_{\text {win, HAF }}$ ) thanks to the airflow window effect which acts as a heat exchanger (Greffet 2016).

The window inner face temperature $T_{\text {win, } \mathrm{HAF}}$ is higher than the operative temperature when the film is activated. This could be an advantage for a more homogenous indoor heating. The operative temperature $\left(T_{\mathrm{op}}\right)$ in the room follows the heating schedule described above. The comparison between $T_{\mathrm{op}}$ and $T_{\text {air,sup,HAF }}$ shows that fresh air introduced into the room is at a higher temperature than the operative temperature of the indoor environment when the heating is on for the case of the heated airflow window.

Figure 7B shows the heat fluxes from the window to the indoor environment of the room by convection $\left(\phi_{\text {conv }}\right)$, radiation $\left(\phi_{\mathrm{rad}}\right)$ and supply of heated fresh air $\left(\phi_{\mathrm{air}}\right)$. It appears that the dominant transfer mode is the longwave thermal radiation, followed by thermal convection and, finally, the supply of heated fresh air (ventilation). Considering the radiative and convective parts described in (ThBCE 2012), it appears that the airflow window integrating a heated glazing unit has a share convection / radiation similar to a floor heating.

The power dissipated by the heating glazing $\left(P_{\text {film }}\right)$ is also represented in Figure 7B making it possible to evaluate the efficiency of the film at each time step. The thermal losses of the window vary according to the external conditions and to the power delivered by the film. The efficiency $E_{\text {film }}$ represents the part of the useful energy that is transferred to the internal environment. The

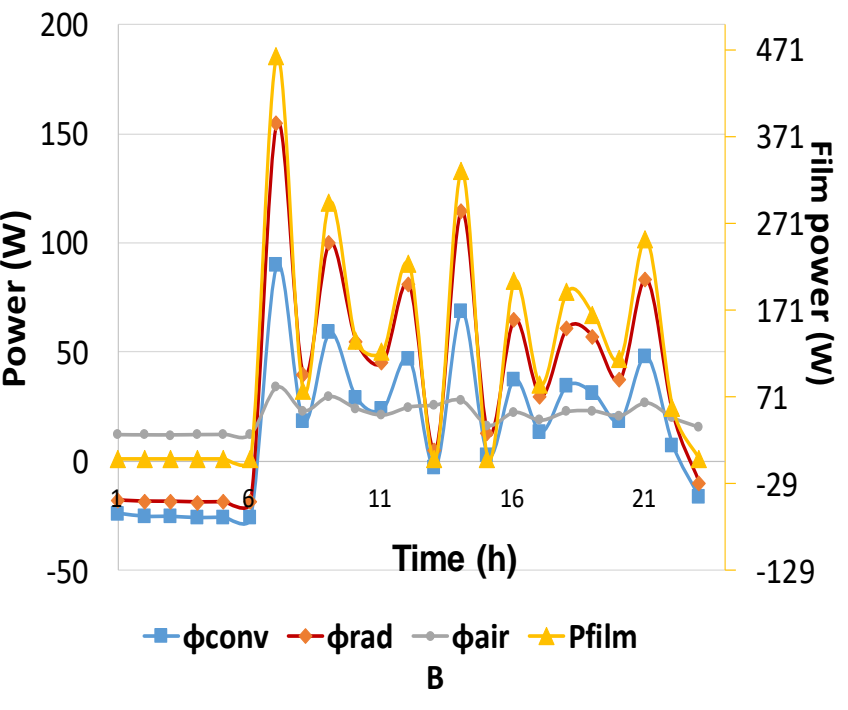

Figure 7: A. Supplied air and inner surface temperatures of the window; B. Heat transfers modes between the heated window and the indoor environment of room 1 (climate of La Rochelle, for a winter day type in January).

Figure 7A shows, for a winter day in January and for the climate of La Rochelle, the blown air temperature ( $\left.T_{\text {air,sup,HAF }}\right)$ and the internal surface temperature $\left(T_{\text {win, } \mathrm{HAF}}\right)$ of the heated airflow window. The surface temperature of a classical airflow window ( $\left.T_{\text {win, AF }}\right)$ is also presented. effectiveness of the heating film $E_{\text {film }}$ (equation (2)) ranges from 0.6 for a high $P_{\text {film }}$ value to 1 if $P_{\text {film }}$ is very low.

$$
E_{\text {film }}=\frac{\Phi_{\text {conv }}+\Phi_{\text {rad }}+\Phi_{\text {air }}}{P_{\text {film }}} \text { if } P_{\text {film }}>0
$$


Around 7 am, we can observe the maximum losses (40\% for $P_{\text {film }}=463 \mathrm{~W}$ ) of this day. Indeed, when $P_{\text {film }}$ is high, the temperature of the outer face of the window is also high causing losses by both convection and long-wave radiations toward the outdoor environment.

\section{Heating energy use: comparison between double-} glazed and airflow windows heated or not

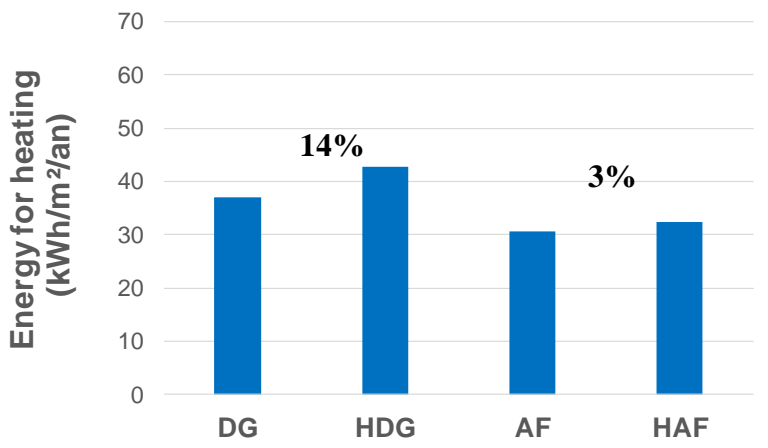

Figure 8: Heating energy use comparison of conventional double-glazed windows and heated airflow windows (climate of La Rochelle).

In Figure 8, the heating energy consumption of the house equipped with heated windows (triple-glazed airflow "HAF" and double-glazed "HDG") is compared to their reference cases ("AF" and "DG"). For reference cases, the building is heated by electric convectors. One can observe that non-heated triple glazed airflow window (AF) helps to reduce heating energy consumption if compared to the double-glazed case (DG). The heating energy is reduced by $17.5 \%$ for the airflow window (AF) case. The energy consumption increases by $14 \%$ for the heated double glazing (HDG) case if compared to the non-heated double-glazed (DG) case. This is due to the part of losses toward the outdoor environment. The energy use increases only by $3 \%$ if compared to the airflow window without heated glass for HAF case. This is due to the air flowing between glass panes of the airflow window leading to heat losses recovery. The HAF case is more efficient than the HDG. In comparison to conventional double-glazed window (DG), the heated triple-glazed airflow window can help to reduce the heating energy by $13 \%$.

\section{Influence of air tightness and building exposure}

Figure 9 shows the annual heating energy consumption for HAF windows case according to the coefficient of air tightness of the building envelope. We consider three values of the coefficient of airtightness $n_{50}=15.2 ; 9.1$ and $2.4 \mathrm{vol} / \mathrm{h}$.

Increasing air infiltration obviously leads to a significant increase in the heating energy consumption and is particularly problematic in the case of heated airflow window since these infiltrations reduce by the same amount the volumes of preheated air flowing through the windows. The heated airflow window requires a building envelope of good quality and is therefore more suitable for new buildings than for existing buildings. In the rest of the study, the air tightness is set to $2.4 \mathrm{vol} / \mathrm{h}$.

Figure 10 shows that, for a given climate (La Rochelle), the exposure of the heated airflow windows has a significant effect on the energy consumption for heating. A comparison to a non-heated airflow windows within a convective electric heating is also provided in Figure 10.

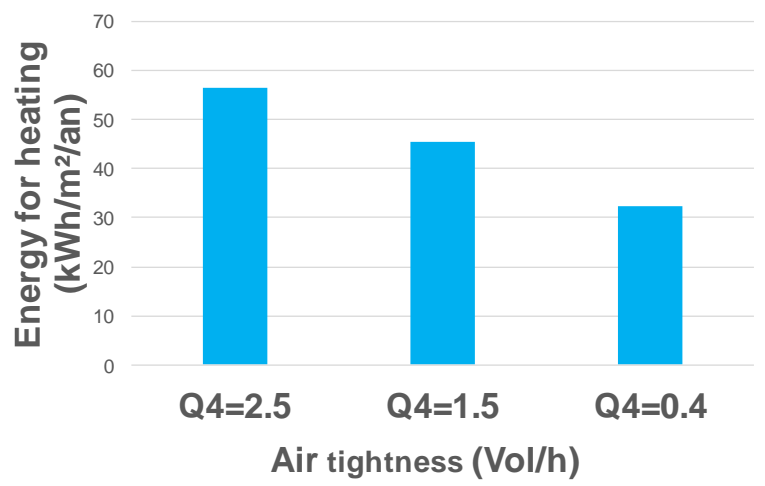

Figure 9: Effects of air tightness of the building envelope (climate of La Rochelle, HAF window).

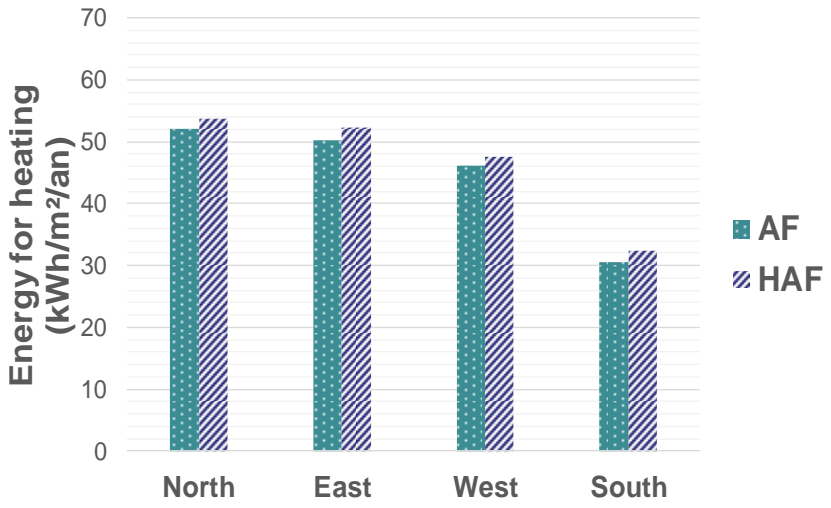

Figure 10: Effects of building window exposure on heating energy consumption (climate of La Rochelle).

This figure shows that, if compared to conventional airflow windows, the final energy consumption for heating increases by $1 \%$ for North and West facing, 2.2 $\%$ for East facing and $3.3 \%$ for South facing. In absolute terms, the increase is lower for South facing. This difference comes from the fact that there is more solar input for South facing. Thus, for other exposures, the need for heating is higher, resulting in a higher electricity consumption. Note that this slight increase in consumption can be compensated by a more homogeneous indoor environment and a gain in living space.

\section{Influence of the climate}

Figure 11 shows heating energy use according to different climate contexts. Here the building is South facing and the air tightness was $n_{50}=2.4 \mathrm{Vol} / \mathrm{h}$ for both cases. Several French locations, are considered, namely Marseille, La Rochelle, Strasbourg and Paris. For continental climates with harsh winters, heating energy consumption is higher 
than for the climates of Marseille and La Rochelle. The relative increases in heating energy compared to "AF" cases are $2 \%$ for Paris and Strasbourg, and $3 \%$ and $6 \%$ respectively for La Rochelle and Marseille. But, in terms of absolute values, the increases of heating energy consumption are higher for climates with harsh winters like Paris and Strasbourg.

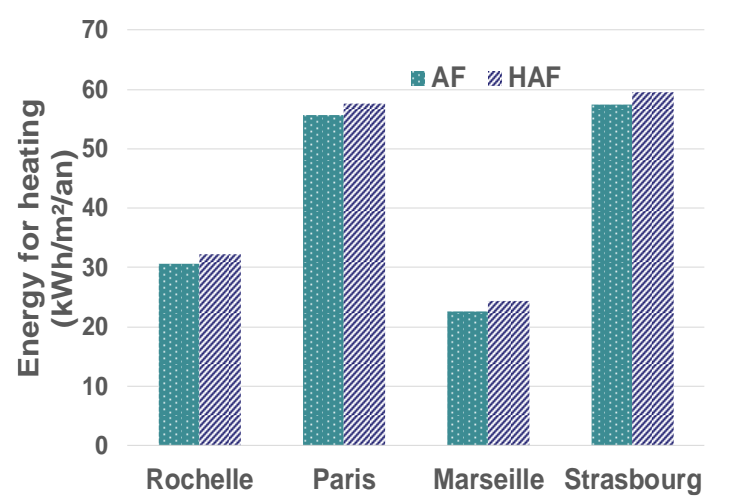

Figure 11: Heating energy consumption according to the building location (climate).

\section{Conclusion}

In order to evaluate the performance of the airflow window equipped with a heated glazing, numerical simulations were carried out by coupling a window model to the building simulation tool TRNSYS $\odot$. Parametric studies were performed for different exposures, different climates and air tightness of envelopes for a typical single-family house, equipped with these windows. Comparisons to conventional double-glazed windows cases were also performed.

The airflow window equipped with heated glazing behaves both as a forced air heating (hot fresh air) and as a radiant heating system (in terms of share convection / radiation during the active periods). The results point out that the heated airflow window case is more efficient than the heated double-glazed one. If compared to conventional double-glazed windows, the use of heated airflow windows helps to decrease the heating energy by $13 \%$.

A slight increase in heating energy consumption is observed depending on the windows exposure and the climate if compared to non-heated airflow window. The heated airflow window can be an alternative to conventional electric heating solutions, leading to a more homogeneous thermal environment and allowing a gain of living space. However, to be effective, it requires a high airtightness of the building envelope. Following this work, studies on thermal comfort, impacts on the optical properties of the glasses, and comparison to conventional heating systems are under way.

\section{Acknowledgement}

This study was carried out as part of the ADEME VARIETO project. The authors want to thank ADEME (Environmental and Energy Management Agency) for its financial contribution.

\section{Nomenclature}

$\begin{array}{ll}\text { AF } & \text { airflow window } \\ \text { DG } & \text { double glazed window } \\ E & \text { efficiency } \\ \text { HAF } & \text { heated airflow window } \\ \text { HDG } & \text { heated double glazed window } \\ n & \text { airtightness, vol/h } \\ p & \text { power density, } \mathrm{W} / \mathrm{m}^{2} \\ P & \text { heating film power, } \mathrm{W} \\ q & \text { airtightness, } \mathrm{m}^{3} \cdot \mathrm{h}^{-1} \cdot \mathrm{m}^{-2} \\ Q & \text { flow, } \mathrm{m}^{3} / \mathrm{h} \\ T & \text { temperature, }{ }^{\circ} \mathrm{C} \\ U & \mathrm{U} \text {-value, } \mathrm{W} /\left(\mathrm{m}^{2} . \mathrm{K}\right) \\ \text { Greek symbols } \\ \Phi & \text { power, } \mathrm{W}\end{array}$

\section{Subscripts and Superscripts}

$\begin{array}{ll}\text { out } & \text { outdoor } \\ \text { film } & \text { heating component } \\ \mathrm{g} & \text { glass } \\ \text { in } & \text { indoor } \\ \text { off } & \text { heating off } \\ \text { on } & \text { heating activated } \\ \text { sup } & \text { supply fresh air } \\ \text { v } & \text { ventilation } \\ \text { win } & \text { window }\end{array}$

\section{References}

Anon Arrêté du 5 février 2015 relatif à l'agrément des modalités de prise en compte des fenêtres pariétodynamiques dans la réglementation thermique 2012.

Anon Arrêté du 24 mars 1982 relatif à l'aération des logements.

Chaussade, P. \& Rigal, F. (1997) Transparent substrate fitted with a stack of silver layers, with application to heated laminated windows. : 5.

DIN V 18599-2 (2007) Energy efficiency of buildings Calculation of the energy needs, delivered energy and primary energy for heating, cooling, ventilation, domestic hot water and lighting - Part 2: Energy needs for heating and cooling of building zones.

Feist, W. \& Schnieders, J. (2009) Energy efficiency - a key to sustainable housing. The European Physical Journal Special Topics, 176 (1): 141-153.

Fremaux, J. \& Brechot, R. (1990) Fenêtre chauffante. , (FR8903809): 9.

Gerhardinger, P. (2003) Next-generation heated glass products. Appliance Magazine.

Granqvist, C.G. \& Hultåker, A. (2002) Transparent and conducting ITO films: new developments and applications. Thin Solid Films, 411 (1): 1-5. 
Greffet, R. (2016) Études expérimentale et numérique des performances énergétiques d'une fenêtre pariétodynamique. Thèse de doctorat en Energétique et thermique, Sous la direction de Patrick Salagnac. Université La Rochelle.

Greffet, R., Michaux, G., Salagnac, P. \& Ridoret, J.-B. (2015) Validation d'un modèle numérique de fenêtre pariétodynamique en conditions in situ. In: Société Française de Thermique. La Rochelle, France, pp.883890.

Greffet, R., Salagnac, P., Michaux, G. \& Ridoret, J.-B. (2013) Airflow window: Numerical study and sensibility analysis of thermal performances. In: BS2013 - 13th International Conference of the International Building Performance Simulation Association. Chambéry, France, pp.413-420.

Kaboré, M., Michaux, G., Greffet, R., Salagnac, P. \& Le Dréau, J. (2018) Etude paramétrique d'une fenêtre pariéto-dynamique intégrant un vitrage chauffant. In: Société Française de Thermique. Pau, pp.801-808.

Kurnitski, J., Jokisalo, J., Palonen, J., Jokiranta, K. \& Seppänen, O. (2004) Efficiency of electrically heated windows. Energy and Buildings, 36 (10): 1003-1010.

Michaux, G., Greffet, R., Salagnac, P. \& Ridoret, J.-B. (2017) Etude numérique des performances thermiques d'une maison individuelle équipée de fenêtres pariétodynamiques. In: Société Française de Thermique. Marseille, France, pp.1049-1056.

Michaux, G., Greffet, R., Salagnac, P. \& Ridoret, J.-B. (2019) Modelling of an airflow window and numerical investigation of its thermal performances by comparison to conventional double and triple-glazed windows. Applied Energy, 242: 27-45.

Ziegler, J.G. \& Nichols, N.B. (1993) Optimum Settings for Automatic Controllers. Journal of Dynamic Systems, Measurement, and Control, 115 (2B): 220-222. 